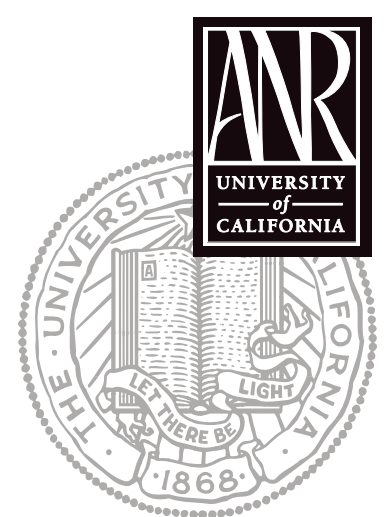

UNIVERSITY OF CALIFORNIA

Division of Agriculture and Natural Resources http://anrcatalog.ucdavis.edu

\title{
Plant Genetic Engineering and Regulation in the United States
}

ALAN McHUGHEN, Cooperative Extension Plant Biotechnologist, Department of Botany and Plant Sciences, University of California, Riverside

Genetic engineering (GE) is the application of recombinant DNA (rDNA) technologies to living organisms to provide new products and enhance existing ones. These products of biotechnology can include insulin and other pharmaceutical and medical applications, specialty enzymes for food production from GE microbes, and GE (also called "transgenic") crops used in agriculture. These products of rDNA are regulated by various government agencies to assure product safety for human health and the environment. This publication describes the U.S. approach to regulating GE plants.

\section{What is the history of recombinant DNA regulation in the United States?}

Genetic engineering started with bacteria in the laboratory in 1973. Although it was a very exciting new research field with plenty of potential applications and benefits, the scientific community itself first recognized the possibility of potential risks associated with this powerful new technology and called a conference to discuss potential biohazards. At the Asilomar Conference of 1975, genetic engineers called for careful restrictions on the use of rDNA technology until the risks could be better evaluated. In response, The National Institutes of Health (NIH) created a recombinant DNA advisory committee (RAC) to establish strict guidelines regulating rDNA research in the laboratory. The guidelines were published in 1976, but they were immediately criticized because they applied only to federally funded research. Nevertheless, U.S. government agencies, including the Environmental Protection Agency (EPA), Food and Drug Administration (FDA), and U.S. Department of Agriculture (USDA), decided to require that any rDNA research done under their auspices comply with the guidelines, effectively mandating compliance for rDNA research funded by the federal government.

It wasn't until the early 1980s that the United States decided to formally regulate GE organisms to assess their safety for human and animal health and the environment, including the agricultural environment. Although many countries later promulgated entirely new laws to regulate rDNA products, the United States chose to adapt existing legislation to accommodate new products derived from rDNA technology. An early study conducted by the National Research Council (NRC) for the National Academies of Science concluded that transgenic methods of plant breeding pose no new categories of risk (NRC 1989). This conclusion of "no new risks with biotechnology" was reiterated in subsequent studies (NRC 2000, 2002, 2004). Based on this early conclusion, the federal government decided to expand the existing regulatory structures. The existing legislation and implementing regulations were brought together by the Office of Science and Technology Policy in a policy document, the Coordinated Framework for Regulation of Biotechnology.

With respect to GE plants, which were first developed in 1983, the USDA began to address agricultural safety by developing regulations under the federal Plant Pest Act (PPA) and the Plant Quarantine Act (PQA) to review plants derived from rDNA technology. Under their relevant respective Acts, the FDA began regulating food and feed safety concerns by developing their policy covering plants and the EPA published regulations covering plants with altered pesticide properties. All of the agencies used their existing authority and expertise to cover evaluation of agricultural, food safety, 
and pesticidal concerns for which they had extensive experience with similar but conventional products. The first approved field trials of GE plants were in 1986, and the first approval that lead to commercial release of a GE food crop was in 1994, the nowdefunct FlavrSavr tomato.

Regulatory oversight continues to evolve as new information becomes available and new studies are conducted. In particular, the NRC has conducted several sciencebased analyses of various aspects of risk associated with rDNA technologies, from environmental effects of GE plants (NRC 2002) to the health effects of GE food (NRC 2004). Federal agencies often sponsor such studies to provide advice on the scientific basis of their regulatory approach.

\section{What are the regulatory steps to get approval for a new GE crop variety?}

Three federal agencies are responsible for evaluating new crop varieties developed using GE: the FDA evaluates food and feed safety aspects, the USDA ensures agricultural and environmental safety, and the EPA evaluates food safety and environmental issues associated with new pesticides and uses. Not all new GE crops need to go through all three agencies. For example, a new ornamental plant with a modified flower color would not need to go to the FDA if it is not used as a food or feed. Similarly, GE crops require EPA review only if they have new pesticidal properties such as insect resistance. In all cases, however, USDA has evaluated new crop plants developed using GE, and the major GE crops currently grown in the United States, including herbicide-tolerant or insect-protected corn, soy, cotton, and canola, were reviewed by all three agencies.

\section{Which agencies are involved?}

\section{USDA}

The U.S. Department of Agriculture, through the Biotechnology Regulatory Service (BRS) office of the Animal and Plant Health Inspection Service (APHIS), regulates all GE plants prior to commercial release. The legislative authority for USDA oversight comes from the Plant Protection Act of 2000. Unlike some countries and jurisdictions, the federal government considers each GE plant a "regulated article" until it is deemed otherwise. The "regulated article" is a plant with a DNA segment inserted using rDNA methods, called an "event." For example, inserting a given gene construct or segment of DNA into a soybean constitutes an "event." Repeating the experiment to obtain a second soybean plant with an identical DNA construct is a second event, and this second GE plant is considered to be regulated, even if the first has received regulatory approval.

The main concern of the USDA is the possibility that the new plant will harm agriculture and the environment. Such harm can come from the plant being modified to increase its ecological fitness and then escaping into the environment, where it would outcompete and displace native plants or become a weed in cultivated lands. To assess this risk, data to characterize the new plant are required, with a focus on the new trait and its effect on ecology. Small-scale field trials are often the first environmental release in which GE plants must comply with regulatory requirements in the research or commercialization stream. After over 12,000 regulated field trials (under the USDA permit system) with GE plants in the United States over almost 20 years, over 60 different GE events have gone on to favorably complete regulatory review (i.e., attain nonregulated status) for commercial release, with the agency deeming the plants "as safe as" their non-GE counterparts (see the Virginia Tech University Information Systems for Biotechnology Web site, http://nbiap.biochem.vt.edu/cfdocs/fieldtestsl.cfm).

In order to grant this "nonregulated" status for GE crops, the USDA requires a molecular, biochemical, and cellular characterization of the GE plant, along with 
data on the life cycle, reproductive characteristics, and any expected or unexpected changes from nonengineered plants of the same species. After the review of a petition for nonregulated status, APHIS issues both an Environmental Assessment and a Determination of Non-Regulated Status. More information on the USDA's regulation of GE plants, along with links to environmental assessment and determination for approved GE plants, can be found at the APHIS Biotechnology Regulatory Services Web site, http://www.aphis.usda.gov/brs/.

\section{FDA}

The Food and Drug Administration is primarily concerned with threats to human health (via food) and to the health of other animals (via feed). The FDA's Center for Food Safety and Nutrition (CFSAN) and the Center for Veterinary Medicine (CVM) evaluate a new GE food (or feed) focusing on the presence of additional or increased allergens and toxins and on any changes to overall nutrition and composition. For example, in assessing a GE soybean with a new gene for disease resistance, FDA scientists consider the normal composition of a regular soybean and compare that with the chemical composition of the new soybean. This comparison includes the usual assortment of proteins, carbohydrates, and other nutrients along with antinutritional factors, toxins, and allergens. As well, FDA scientists consider the source of a new gene. Was the donor an allergenic or toxic plant or microbe? If so, the soybean will require more extensive analysis to assure that the allergenic or toxic properties have not been transferred along with the useful trait.

One criticism of the regulatory process is that the FDA's system is "voluntary," so developers of a new biotech-derived food crop could legally place it on the market without FDA's knowledge or approval. While this is technically true, in practice all GE-derived food and feed crops have gone to the FDA for a "consultation." Because the focus of the FDA is on the safety of the food or feed product, the questions they ask are based on common sense (e.g., Are there any new allergens or toxins in the food?) and provide the developer with a careful, independent consultation on the safety of the product.

To date, the FDA has consulted on nearly 100 GE foods and feeds. Upon completion of the consultation, the FDA issues a memo summarizing the characteristics of the food or feed and their implications for safety. The FDA does not formally "approve" the product as being safe, but rather "completes" the consultation evaluating whether the product is any different, materially or regarding safety, compared with its unmodified counterpart. For more information on the FDA's role in the regulation of GE, see FDA 2004 and the FDA Biotechnology Web site, http://vm.cfsan.fda.gov/ lrd/biotechm.html.

\section{EPA}

The Environmental Protection Agency is mainly concerned with the environmental and human health impacts of pesticides. EPA regulates GE plants that have altered pesticide characteristics, no matter whether they require a shift in the kind or amount of pesticide used. For example, Roundup Ready soybeans were genetically modified to survive exposure to Roundup herbicide, so EPA demanded an assessment. Technically, they do not assess the soybean plant, but rather the new use of the Roundup herbicide.

Similarly, GE Bt corn can be cultivated without being sprayed with Bt insecticide because the plant itself produces $\mathrm{Bt}$, which deters susceptible insect pests from eating the plant. Because the GE corn plant itself produces Bt and alters the insecticide regime, EPA refers to this as "plant incorporated protectant" (PIP) and claims regulatory oversight. For information on EPA regulatory activity involving GE products, see the EPA Science Coordination and Policy Regulatory Framework Web site, http://www.epa.gov/scipoly/biotech/framework.htm. 


\section{Are GE projects subject to other reviews?}

In addition to the USDA, FDA, and EPA review of new GE crop varieties, new crop varieties, whether genetically engineered or modified using conventional breeding, must also conform to quality standards set by plant breeders and the seed industry. For example, the international treaty for protection of new seed varieties, the International Union for the Protection of New Varieties of Plants (UPOV), demands that new varieties cannot be registered unless they meet "DUS" standards. That is, the new variety must be genetically distinct (D) from other existing varieties, the crop must have a uniform (U) appearance in the field, and the traits must be genetically stable (S) over many generations. Also, the Organization for Economic Cooperation Development (OECD) sets international trading standards for many commodities, including grain. Although not all of these standards are related to human health or the environment, they do serve to assure a set standard, particularly in regard to uniformity and genetic stability of new crop varieties. Robust evaluation of agronomic characteristics helps assure that minimal unpredicted genetic characteristics will arise.

\section{What are the implications of regulation for California agriculture?}

California agriculture currently grows GE varieties of only two main crops, cotton and corn. Part of the reason for this is that GE crop developers have focused mainly on the large-acreage crops-corn, soybean, cotton, and canola—and not on the hundreds of other specialty crops and commodities of importance to California agriculture. According to a recent conference on the regulatory status of specialty biotech crops (see Goldner et al. 2004), a major reason for this situation is the lengthy and expensive regulatory process required of biotech crops prior to their release to farmers and consumers. Many of California's specialty crops and other farm products are too small in acreage and overall value to justify the substantial costs of regulatory compliance and processing. That is, the value of a biotech variety of avocado, for example, would not generate sufficient revenue to justify the costs of obtaining regulatory authority to market the new avocado. As a result, farmers and consumers of these smaller-market crops are not able to utilize GE varieties in their production systems.

\section{PERSPECTIVE}

Genetic engineering is a powerful technology capable of providing great benefits, but it also could carry risks. To evaluate this possibility, the technology and its resulting products have always been highly regulated in the United States, and the scientific basis for the regulatory oversight is under constant review by the scientific community as well as by the relevant federal and state government agencies. As a result, crops and foods derived from genetic engineering receive greater regulatory safety evaluation prior to commercial release than any other crops or foods in the history of agriculture. This regulatory framework ensures that the safety of genetically engineered crops is superior or at least comparable to the safety of conventionally produced crops, although regulatory costs for GE crops are much higher than for conventional ones.

\section{REFERENCES}

APHIS (Animal and Plant Health Inspection Service) Biotechnology Regulatory Services Web site, http://www.aphis.usda.gov/brs/.

Goldner, W. R., A. M. Thro, and J. W. Radin, eds. 2004. Public research and the regulatory review of small-market (specialty) biotechnology-derived crops workshop proceedings. USDA Cooperative State Research, Education, and Extension Service Web site, http://www.csrees.usda.gov/nea/biotech/pdf/small_mkt.pdf.

EPA (U.S. Environmental Protection Agency). Science Coordination and Policy Regulatory Framework Web site, http://www.epa.gov/scipoly/biotech/framework.htm. 
FDA (U.S. Food and Drug Administration). 2004. Recommendations for the early food safety evaluation of new non-pesticidal proteins produced by new plant varieties intended for food use. U.S. FDA Biotechnology Web site, http://www.cfsan.fda.gov/ dms/bioprgui.html.

NRC (National Research Council). 1989. Field testing genetically modified organisms: Framework for decision. Washington, DC: National Academy Press.

-2000. Genetically modified pest protected plants: Science and regulation. Washington, DC: National Academy Press.

- 2002. Environmental effects of GE plants. The scope and adequacy of regulation. Washington, DC: National Academy Press.

- 2004. Safety of genetically engineered foods. Approaches to assessing unintended health effects. Washington, DC: National Academy Press.

Office of Science and Technology Policy. 1986. Coordinated framework for regulation of biotechnology. U.S. Regulatory Agencies Unified Biotechnology Web site, http://usbiotechreg.nbii.gov/Coordinated_Framework_1986_Federal_ Register.html.

Virginia Tech University. Information Systems for Biotechnology, Field Test Releases in the U.S. Web site, http://nbiap.biochem.vt.edu/cfdocs/fieldtestsl.cfm

To order or obtain printed ANR publications and other products, visit the ANR Communication Services online catalog at http://anrcatalog.ucdavis.edu. You can also place orders by mail, phone, or FAX, or request a printed catalog of our products from:

University of California

Agriculture and Natural Resources

Communication Services

6701 San Pablo Avenue, 2nd Floor

Oakland, California 94608-1239

Telephone: (800) 994-8849 or (510) 642-2431

FAX: (510) 643-5470

E-mail inquiries: danrcs@ucdavis.edu

An electronic version of this publication is available on the ANR Communication Services Web site at http://anrcatalog.ucdavis.edu.

Publication 8179

(C) 2006 by the Regents of the University of California, Division of Agriculture and Natural Resources. All rights reserved.

The University of California prohibits discrimination or harassment of any person on the basis of race, color, national origin, religion, sex, gender identity, pregnancy (including childbirth, and medical conditions related to pregnancy or childbirth), physical or mental disability, medical condition (cancer-related or genetic characteristics), ancestry, marital status, age, sexual orientation, citizenship, or status as a covered veteran (covered veterans are special disabled veterans, recently separated veterans, Vietnam era veterans, or any other veterans who served on active duty during a war or in a campaign or expedition for which a campaign badge has been authorized) in any of its programs or activities. University policy is intended to be consistent with the provisions of applicable State and Federal laws.

Inquiries regarding the University's nondiscrimination policies may be directed to the Affirmative Action/Staff Personnel Services Director, University of California, Agriculture and Natural Resources, 1111 Franklin Street, 6th Floor, Oakland, CA 94607-5201, (510) 987-0096. For a free catalog of other publications, call (800) 994-8849. For help downloading this publication, call (530) 754-5112.

To simplify information, trade names of products have been used. No endorsement of named or illustrated products is intended, nor is criticism implied of similar products that are not mentioned or illustrated.

This publication has been anonymously peer reviewed for technical accuracy by University of California scientists and other qualified professionals. This review process was managed by the ANR Associate Editor for Animal, Avian, Aquaculture, and Veterinary Sciences. 